\title{
Site-Specific Transglutaminase-Mediated Conjugation of Interferon $\alpha-2 b$ at Glutamine or Lysine Residues
}

Barbara Spolaore, ${ }^{*, \dagger}, \stackrel{\dagger}{ }$ Samanta Raboni $,{ }^{\dagger}, \perp$ Abhijeet A. Satwekar, ${ }^{\ddagger}, \#$ Antonella Grigoletto, ${ }^{\dagger}$ Anna Mero, ${ }^{\dagger}$ Isabella Monia Montagner, ${ }^{\S}$ Antonio Rosato, ${ }^{\S}, \|$ Gianfranco Pasut, ${ }^{*},, \S$ and Angelo Fontana ${ }^{\ddagger}$

${ }^{\dagger}$ Department of Pharmaceutical and Pharmacological Sciences, University of Padua, via Francesco Marzolo 5, 35131 Padua, Italy

${ }^{\ddagger}$ CRIBI Biotechnology Centre, University of Padua, viale Giuseppe Colombo 3, 35121 Padua, Italy

${ }^{\S}$ Veneto Institute of Oncology IOV - IRCCS, via Gattamelata 64, I-35128 Padua, Italy

"Department of Surgery, Oncology, and Gastroenterology, University of Padua, via Nicolò

Giustiniani 2, 35124 Padua, Italy

Address correspondence to: barbara.spolaore@unipd.it; gianfranco.pasut@unipd.it.

CONTENTS:

Figure S1. TGase-mediated oligomerization of IFN.

Figure S2. MS/MS mass spectrum of the doubly charged ion at $520.27 \mathrm{~m} / \mathrm{z}$ of peptide $160-165$ of IFN modified at Lys164 with ZQG.

Figure S3. MS ${ }^{\mathrm{E}}$ fragment ion spectra of peptides $1-42$ and $1-42^{1 \mathrm{ZQG}}$

Figure S4. MS/MS mass spectrum of the doubly charged ion at $697.37 \mathrm{~m} / \mathrm{z}$ of peptide $97-107$ of IFN modified at Gln101 with DC.

Figure S5. Limited proteolysis of IFN with proteinase K.

Figure S6. Purification of IFN ${ }^{1 \mathrm{PEG}(\mathrm{K} 164)}$ and $\mathrm{IFN}^{1 \mathrm{PEG}(\mathrm{Q} 101)}$ derivatives.

Figure S7. Characterization of the purified $\mathrm{IFN}^{1 \mathrm{PEG}(\mathrm{K} 164)}$ and IFN ${ }^{1 \mathrm{PEG}(\mathrm{Q} 101)}$ derivatives by MALDITOF mass spectrometry and by RP-HPLC.

Table S1. Molecular masses of IFN oligomers produced upon incubation of IFN with TGase for 4 h.

Table S2. Peptides of IFN identified in the digest of native IFN with endoprotease Glu-C.

Table S3. Peptides of IFN identified in the digest of IFN ${ }^{1 Z Q G}$ with endoprotease Glu-C.

Table S4. Peptides of IFN identified in the digest of IFN ${ }^{1 \mathrm{DC}}$ with endoprotease Glu-C.

Table S5. Calculated and measured $\mathrm{m} / \mathrm{z}$ values of the fragment ions detected in the $\mathrm{MS}^{\mathrm{E}}$ fragment ion spectra of peptides $1-42$ and $1-42^{1 \mathrm{ZQG}}$.

Table S6. Molecular masses of the nicked forms of IFN produced by limited proteolysis with proteinase $\mathrm{K}$ before and after reduction with TCEP. 

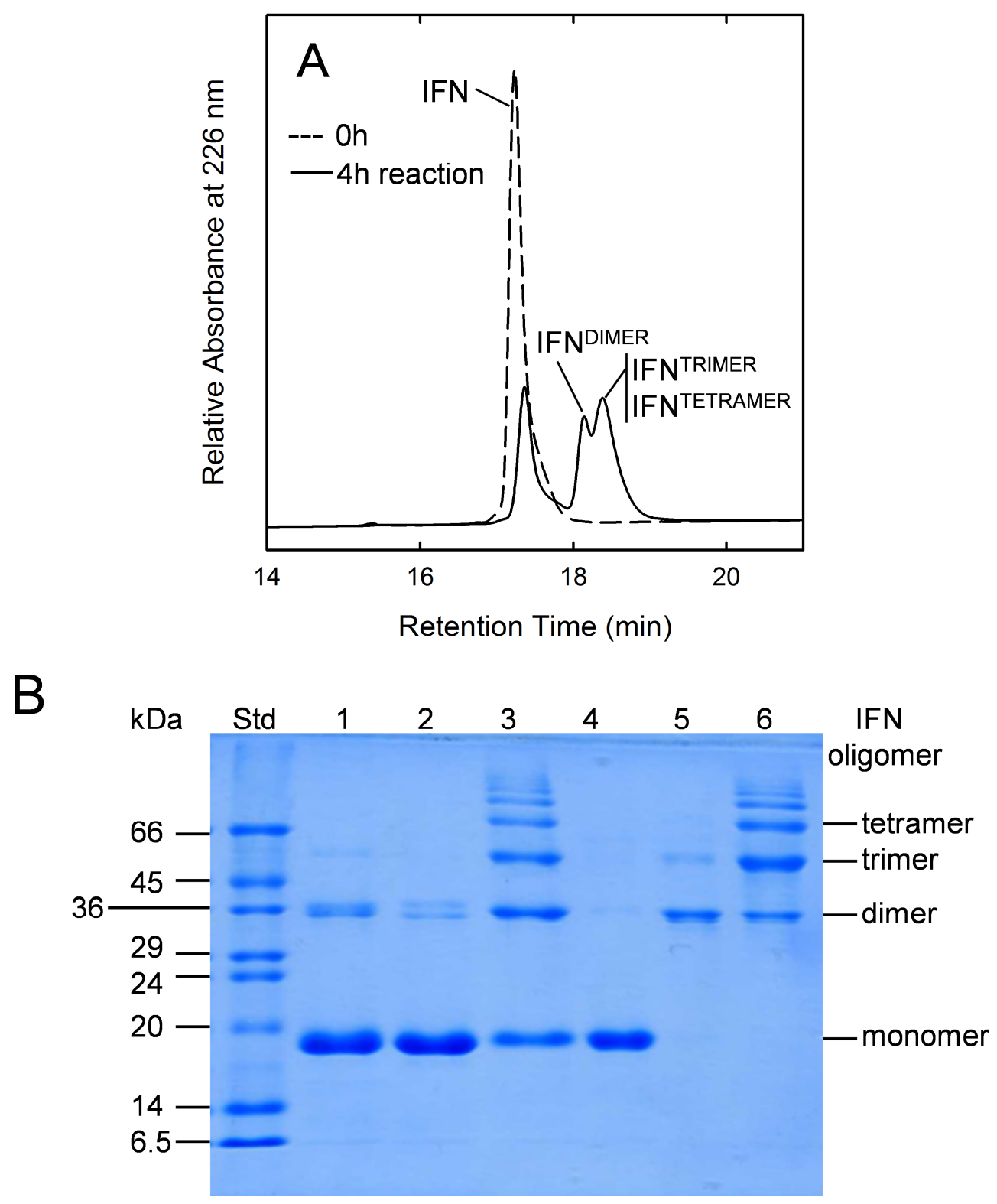

Figure S1. TGase-mediated oligomerization of IFN. A. RP-HPLC analysis of the IFN oligomeric species formed upon incubation with TGase. A dashed line and a straight line indicate the chromatograms of native IFN and of the reaction mixture after $4 \mathrm{~h}$ of incubation, respectively. B. SDS-PAGE analysis (15\%) of the reaction mixtures of IFN with DC or ZQG and TGase or in the presence of TGase only, after $4 \mathrm{~h}$ of incubation. Protein samples were loaded in the following order: MW standards (Std); IFN incubated with ZQG and TGase for $4 \mathrm{~h}$ (lane 1); IFN incubated with DC and TGase for $4 \mathrm{~h}$ (lane 2); IFN incubated with TGase only for $4 \mathrm{~h}$ (lane 3); protein material eluted in the RP-HPLC analysis reported in (A) and collected at $17.4 \mathrm{~min}$ (IFN, lane 4), $18.1 \mathrm{~min}$ $\left(\right.$ IFN $^{\text {DIMER }}$, lane 5) and $18.4 \min ^{\left(I F N^{\text {TRIMER }}\right.}$ IFN $^{\text {TETRAMER }}$, lane 6). 


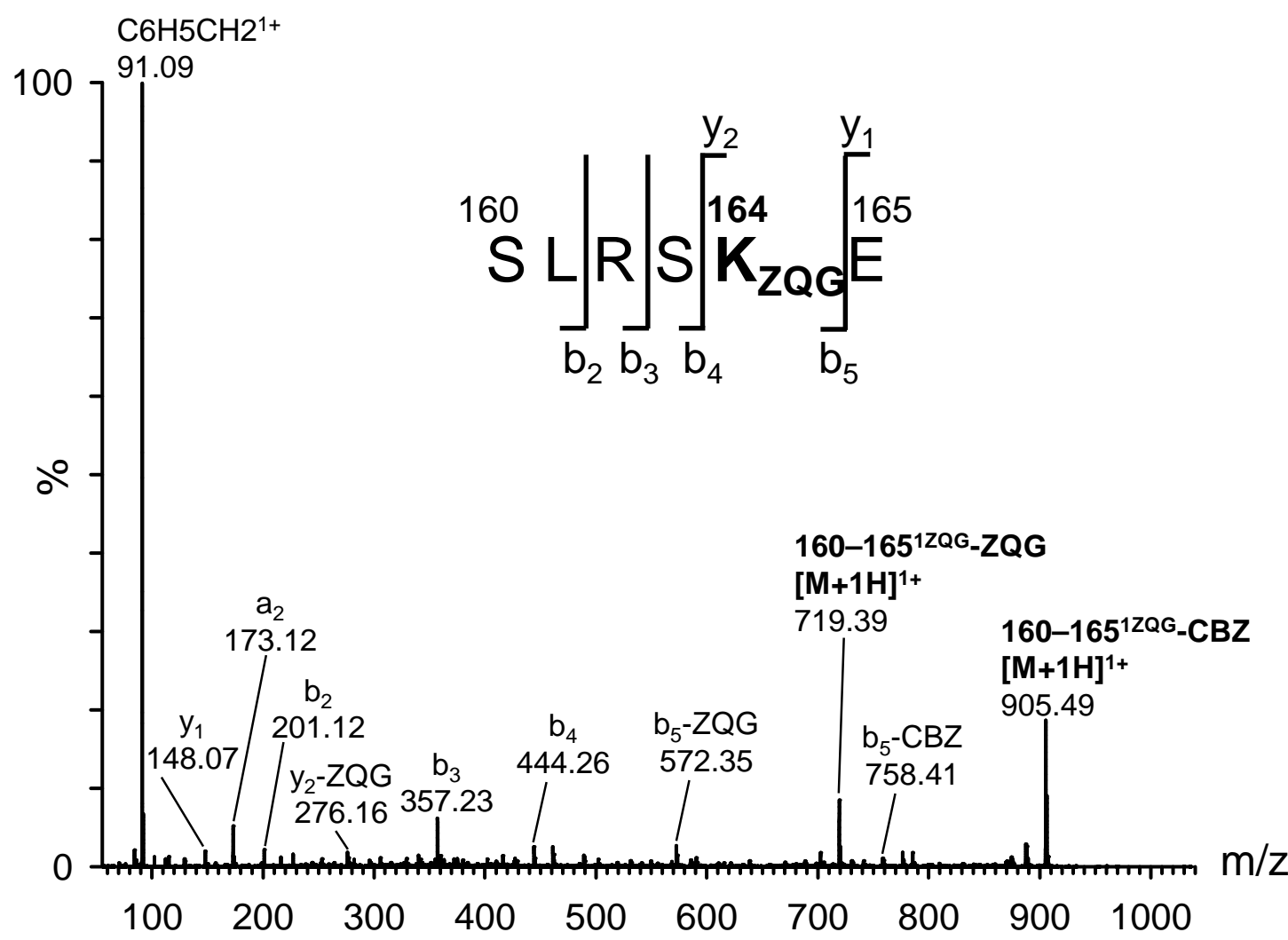

Figure S2. MS/MS mass spectrum of the doubly charged ion at $520.27 \mathrm{~m} / \mathrm{z}$ of peptide $160-165$ of IFN modified at Lys164 with ZQG. In the MS/MS spectrum, ions assigned to fragments of the series $y$ and $b$ are indicated. Fragments containing Lys 164 show a mass increment corresponding to the conjugation of ZQG. For some fragment ions, fragment species derived from the removal of ZQG (-ZQG) or of the carbobenzoxy group (-CBZ) were also detected. The MS/MS analysis of the modified peptide was conducted on the Q-Tof Micro mass spectrometer. In the insert, fragments of the series $b$ and $y$ that were identified in the MS/MS spectrum are indicated on the sequence of the peptide. Lys 164 is indicated in bold as $\mathrm{K}_{\mathrm{ZQG}}$. 

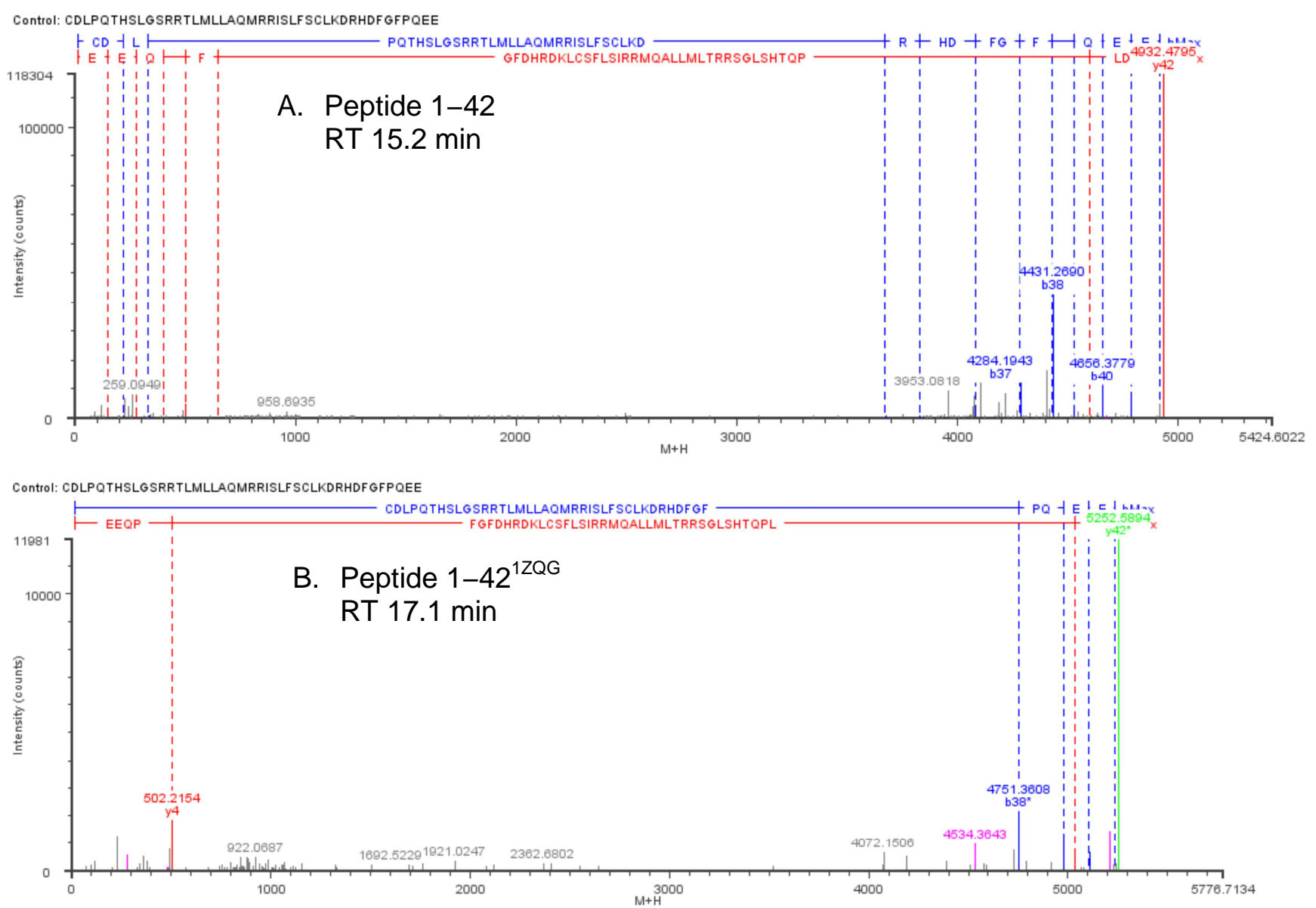

Figure S3. $\mathrm{MS}^{\mathrm{E}}$ fragment ion spectra of peptides $1-42$ (A) and $1-42^{1 \mathrm{ZQG}}$ (B). The spectra were derived from the $\mathrm{LC}-\mathrm{MS}^{\mathrm{E}}$ analysis of the digest of IFN ${ }^{1 \mathrm{ZQG}}$ with endoprotease Glu-C processed with the BiopharmaLynx 1.3.4 Software (Waters). In the spectra, the y ion peaks are colored in red and the $b$ ions in blue. Fragment ions that match other peptides are highlighted in magenta, while unmatched are gray. Measured and calculated $\mathrm{m} / \mathrm{z}$ values of the $\mathrm{y}$ and $\mathrm{b}$ ions are reported in Table S5. 


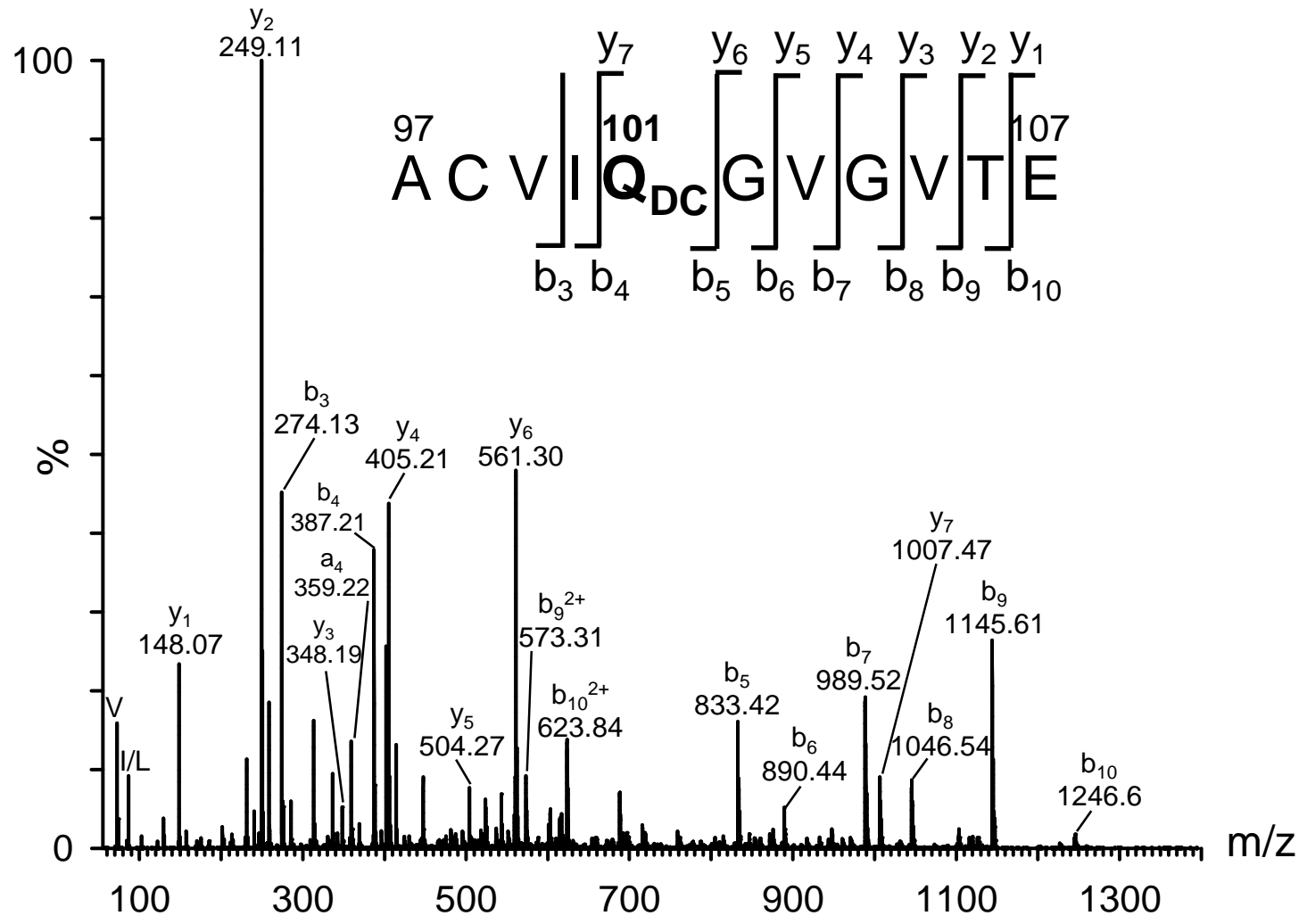

Figure S4. MS/MS mass spectrum of the doubly charged ion at $697.37 \mathrm{~m} / \mathrm{z}$ of peptide $97-107$ of IFN modified at Gln101 with DC. In the MS/MS spectrum, ions assigned to fragments of the series $\mathrm{y}$ and $\mathrm{b}$ are indicated. Fragments containing Gln101 show a mass increment corresponding to the conjugation of DC. The MS/MS analysis of the modified peptide was conducted on the Q-Tof Micro mass spectrometer. In the insert, fragments of the series $b$ and $y$ that were identified in the MS/MS spectrum are indicated on the sequence of the peptide. Gln101 is indicated in bold as $\mathrm{QDC}_{\mathrm{DC}}$ 
A CDLPQTHSLG SRRTLMLLAQ MRRIS LFSCL KDRHDFGFPQ EEFGNQFQKA 50

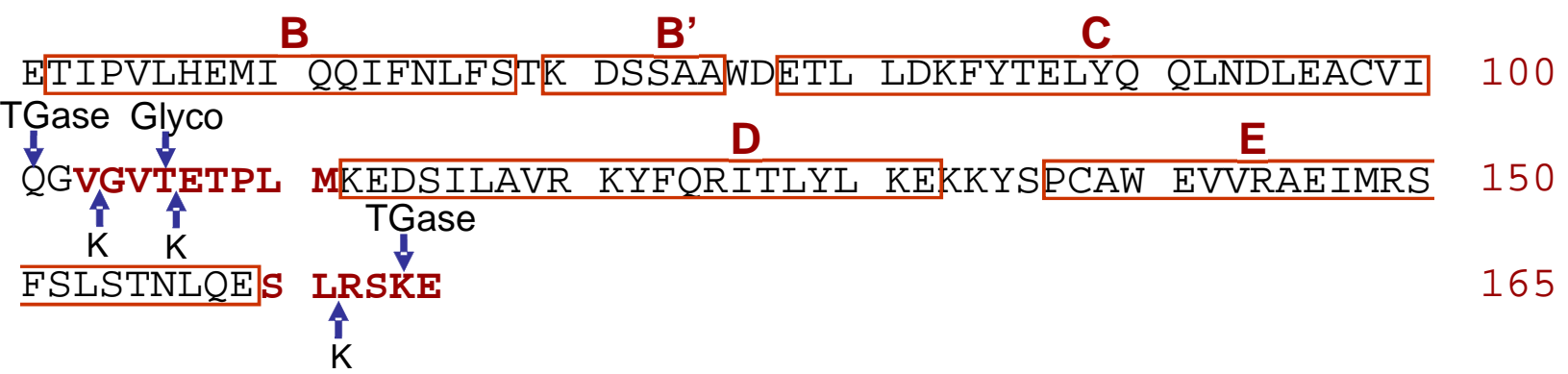

B
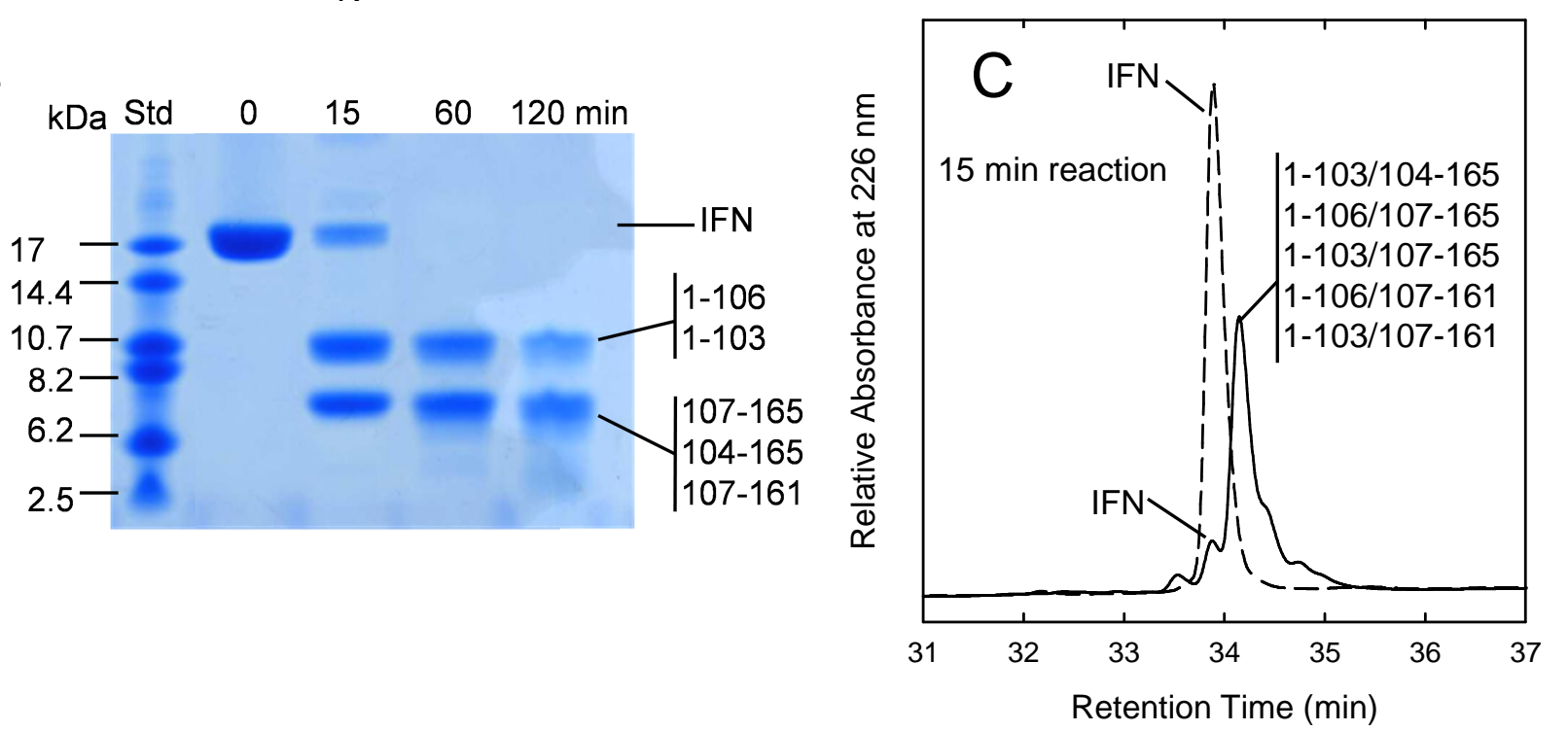

Figure S5. Limited proteolysis of IFN with proteinase K. A. Amino acid sequence of IFN $\alpha-2 b$. Red boxes show the position of helices according to the X-ray structure of the protein (PDB file 1RH2) while amino acid residues located in highly flexible regions of the protein structure showing no electron density are colored in bold red. The Gln and Lys residues sites of TGase modification (TGase) are indicated by arrows, as well as the sites of limited proteolysis by proteinase $\mathrm{K}(\mathrm{K})$ and the site of glycosylation in vivo (Glyco). B. Time course analysis by SDS-PAGE of the proteolysis reaction. Aliquots from the reaction mixtures were quenched at the indicated times of incubation and then analyzed by tricine SDS-PAGE under reducing conditions. On the right side of the lanes the identities of the fragments are indicated, as determined by means of mass spectrometric measurements. The partial BrCN-digest of horse heart myoglobin $(17 \mathrm{kDa})$ served as molecular marker and is shown on the left side of the gel. C. RP-HPLC analysis of the reaction mixture of IFN reacted with proteinase $\mathrm{K}$ after 15 min of incubation. Limited hydrolysis of the protein leads to several species given by fragments covalently linked to each other by the two disulfide bridges of the protein (Cys1-Cys98 and Cys29-Cys138). 


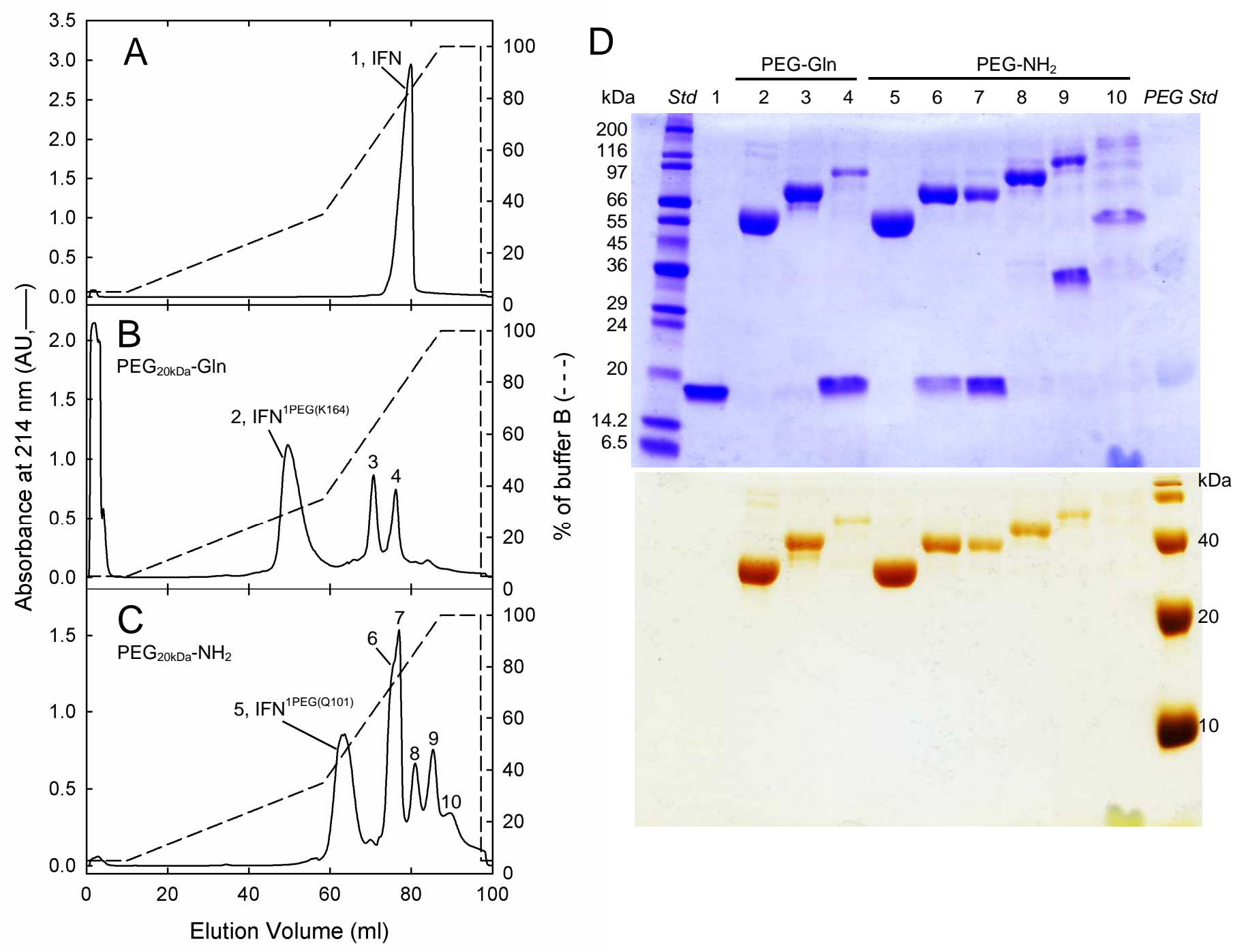

Figure S6. Purification of $\mathrm{IFN}^{1 \mathrm{PEG}(\mathrm{K} 164)}$ and $\mathrm{IFN}^{1 \mathrm{PEG}(\mathrm{Q} 101)}$ derivatives. Strong cation exchange chromatography of IFN (A) and of the reaction mixtures containing IFN, TGase and PEG $20 \mathrm{kDa}-\mathrm{Gln}$ (B) or $\mathrm{PEG}_{20 \mathrm{kDa}}-\mathrm{NH}_{2}$ (C) after $5 \mathrm{~h}$ of incubation (see Fig. 4, main text). Samples were loaded on a RESOURCE S column. The column was eluted with a gradient of buffer A (10 mM sodium phosphate $\mathrm{pH} 4.7)$ and $\mathrm{B}(0.1 \mathrm{M}$ sodium phosphate, $0.1 \mathrm{M} \mathrm{NaCl} \mathrm{pH} 4.85)$. For each chromatogram, a straight line and a dashed line indicate the absorbance at $214 \mathrm{~nm}$ and the $\%$ of buffer B, respectively. Samples collected from the cation exchange chromatography were analyzed by SDSPAGE (Mini-PROTEAN TGX Precast gel 8-16\%, BIO-RAD) and stained with Coomassie Stain and iodine (D). Std is SigmaMarker Wide Range, while PEG Std are PEG polymers of 10, 20 and $40 \mathrm{kDa}$. Samples (approximately $2 \mu \mathrm{g}$ ) were loaded as follow: 1, IFN; 2, IFN ${ }^{1 \mathrm{PEG}(\mathrm{Q} 101)}$; 3-4, fractions collected at 70 and $76 \mathrm{~min}$, respectively in the cation exchange analysis reported in B; 5 IFN $^{1 \mathrm{PEG}(\mathrm{K} 164)}$ and 6-10, fractions collected at 75, 77, 81, 86 and $90 \mathrm{~min}$, respectively in the cation exchange analysis reported in $\mathrm{C}$. The number of each lane is also reported on the corresponding peak of the cation exchange chromatograms. 

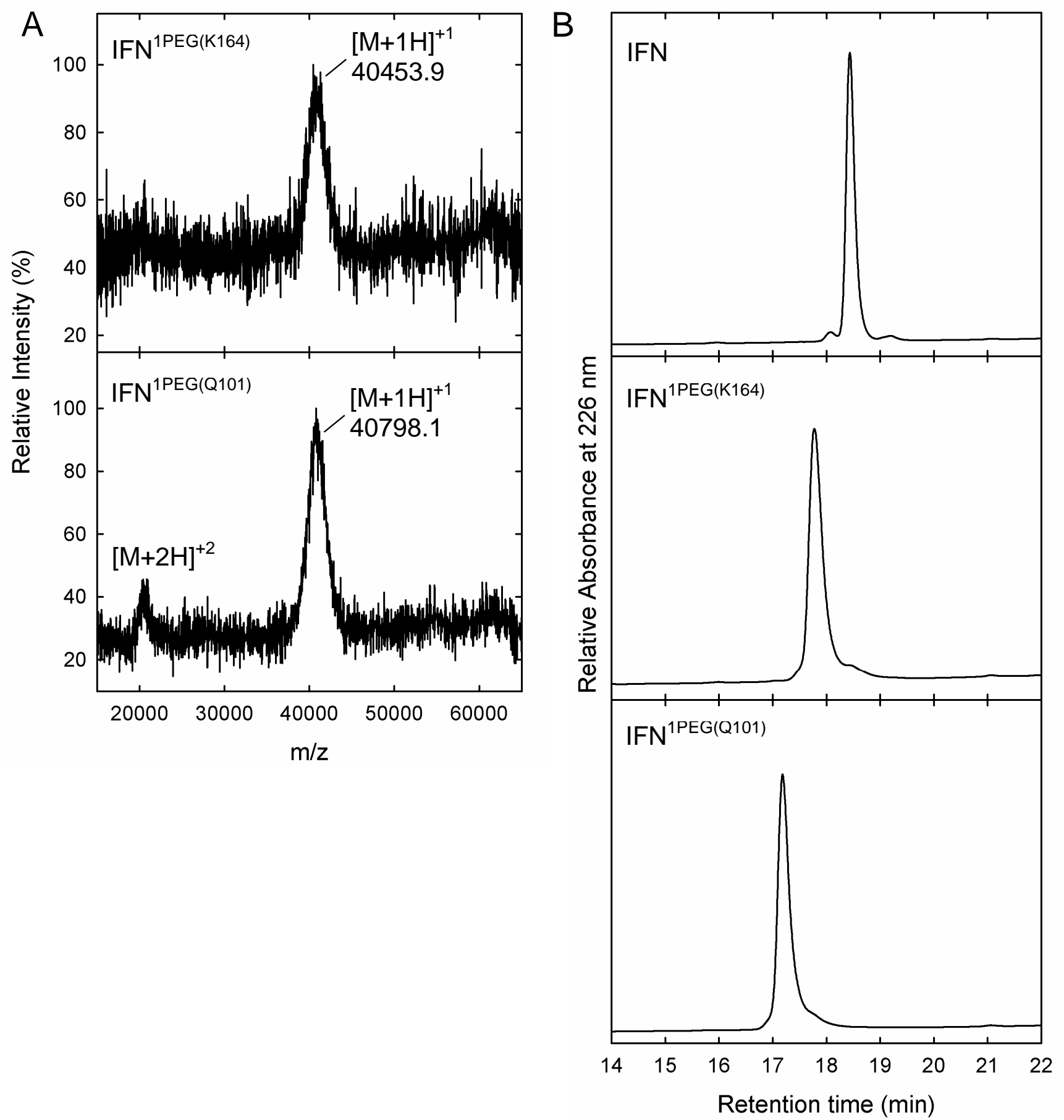

Figure S7. Characterization of the purified IFN ${ }^{1 \mathrm{PEG}(\mathrm{K} 164)}$ and $\mathrm{IFN}^{1 \mathrm{PEG}(\mathrm{Q} 101)}$ derivatives by MALDITOF mass spectrometry and by RP-HPLC. A. MALDI-TOF mass spectra acquired on the derivatives IFN ${ }^{1 \mathrm{PEG}(\mathrm{K} 164)}$ and $\mathrm{IFN}^{1 \mathrm{PEG}(\mathrm{Q} 101)}$. The $\mathrm{m} / \mathrm{z}$ values of the single charge state peaks of the derivatives are indicated in each spectrum. B. RP-HPLC analyses of IFN and of the conjugated species after collection from the cation exchange chromatography. The conditions of the RP-HPLC analyses were the same used for the analyses of the reaction mixtures (see Fig. 4, main text). 
Table S1. Molecular masses of IFN oligomers produced upon incubation of INF with TGase for 4 h.

\begin{tabular}{lccc}
\hline \multirow{2}{*}{ IFN species } & \multirow{2}{*}{ RT (Min) } & \multicolumn{2}{c}{ Molecular mass (Da) } \\
\cline { 3 - 4 } & & Found $^{a}$ & Calculated $^{b}$ \\
\hline IFN & 17.36 & $19265.92 \pm 0.61$ & 19265.16 \\
IFN $^{\text {DIMER }}$ & 18.14 & $38513.43 \pm 0.50$ & 38513.28 \\
IFN $^{\text {TRIMER }}$ & 18.38 & $57764.77 \pm 0.52$ & 57761.41 \\
IFN $^{\text {TETRAMER }}$ & 18.38 & $77013.20 \pm 0.77$ & 77009.53 \\
\hline
\end{tabular}

ESI-MS analyses were performed on the protein material collected in the RP-HPLC analysis reported in Fig. S1A. ${ }^{a}$ Experimental molecular masses determined by ESI-MS. ${ }^{b}$ Calculated average molecular masses. 
Table S2. Peptides of IFN identified in the digest of native IFN with endoprotease Glu-C.

\begin{tabular}{|c|c|c|c|c|c|c|c|c|c|c|}
\hline Peptide $^{a}$ & Start & End & Modifiers & RT (Min) & $\begin{array}{l}\text { Calculated } \\
\text { Mass (Da) }\end{array}$ & $\begin{array}{c}\text { Measured } \\
\text { Mass } \\
\text { (Da) }\end{array}$ & $\begin{array}{l}\text { Error } \\
(p p m)\end{array}$ & $\begin{array}{c}\text { b/y } \\
\text { Possible }\end{array}$ & $\begin{array}{c}\text { b/y } \\
\text { Found }\end{array}$ & $\begin{array}{l}\text { Intensity } \\
\text { (Counts) }\end{array}$ \\
\hline $\begin{array}{l}\text { CDLPQTHSLGSRRTLMLLAQM } \\
\text { RRISLFSCLKDRHDFGFPQEE }\end{array}$ & 1 & 42 & - & 15.2 & 4931.4565 & 4931.4785 & 4.5 & 82 & 4 & 245333 \\
\hline $\begin{array}{l}\text { DSILAVRKYFQRITLYLKEKKY } \\
\text { SPCAWE }\end{array}$ & 114 & 141 & - & 15.8 & 3447.8376 & 3447.8523 & 4.3 & 54 & 1 & 29322 \\
\hline DSILAVRKYFQRITLYLKE & 114 & 132 & - & 15.9 & 2355.3313 & 2355.3442 & 5.5 & 36 & 0 & 9668 \\
\hline MIQQIFNLFSTKDSSAAWDE & 59 & 78 & - & 17.2 & 2330.0889 & 2330.0959 & 3 & 38 & 10 & 37057 \\
\hline ACVIQGVGVTETPLMKE & 97 & 113 & - & 13.7 & 1773.9005 & 1773.9061 & 3.2 & 32 & 14 & 30243 \\
\hline IMRSFSLSTNLQE & 147 & 159 & - & 13.2 & 1524.7606 & 1524.7638 & 2.1 & 24 & 13 & 64326 \\
\hline LYQQLNDLE & 88 & 96 & - & 12.6 & 1134.5557 & 1134.5588 & 2.7 & 16 & 9 & 42470 \\
\hline TLLDKFYTE & 79 & 87 & - & 13.6 & 1128.5703 & 1128.5741 & 3.4 & 16 & 10 & 76736 \\
\hline KKYSPCAWE & 133 & 141 & - & 10.6 & 1110.5168 & 1110.5195 & 2.4 & 16 & 0 & 2678 \\
\hline ACVIQGVGVTE & 97 & 107 & - & 12.5 & 1074.538 & 1074.542 & 3.7 & 20 & 7 & 20263 \\
\hline FGNQFQKAE & 43 & 51 & - & 9.8 & 1067.5035 & 1067.5049 & 1.3 & 16 & 10 & 59775 \\
\hline TIPVLHE & 52 & 58 & - & 11.5 & 807.449 & 807.4523 & 4.1 & 12 & 4 & 74896 \\
\hline SLRSKE & 160 & 165 & - & 2.7 & 718.3973 & 718.4009 & 5 & 10 & 5 & 48263 \\
\hline TPLMKE & 108 & 113 & - & 9.3 & 717.3731 & 717.3762 & 4.3 & 10 & 2 & 10852 \\
\hline VVRAE & 142 & 146 & - & 5.8 & 572.3282 & 572.3318 & 6.3 & 8 & 1 & 6308 \\
\hline
\end{tabular}

${ }^{a}$ Identified peptides with zero missed cleavages are reported. Peptides derived from one missed cleavage are only peptide 114-141 and peptide $97-$ 113. Peptide 114-141 is reported because the two peptides 114-132 and 133-141 have low intensities, while peptide 97-113 is of interest for the modification of IFN with ZQG. 
Table S3. Peptides of IFN identified in the digest of IFN ${ }^{1 Z Q G}$ with endoprotease Glu-C.

\begin{tabular}{|c|c|c|c|c|c|c|c|c|c|c|}
\hline Peptide $^{a}$ & Start & End & $\begin{array}{l}\text { Modifiers } \\
\text { (\% modified, } \\
\text { residue })^{b}\end{array}$ & $\begin{array}{c}\text { RT } \\
\text { (Min) }\end{array}$ & $\begin{array}{l}\text { Calculated } \\
\text { Mass (Da) }\end{array}$ & $\begin{array}{l}\text { Measured } \\
\text { Mass (Da) }\end{array}$ & $\begin{array}{l}\text { Error } \\
(\mathrm{ppm})\end{array}$ & $\begin{array}{c}\text { b/y } \\
\text { Possible }\end{array}$ & $\begin{array}{c}\text { b/y } \\
\text { Found }\end{array}$ & $\begin{array}{l}\text { Intensity } \\
\text { (Counts) }\end{array}$ \\
\hline $\begin{array}{l}\text { CDLPQTHSLGSRRTLMLLA } \\
\text { QMRRISLFSCLKDRHDFGFP } \\
\text { QEE }\end{array}$ & 1 & 42 & $\begin{array}{c}\text { ZQG(1) } \\
(4.7 \%, \mathrm{~K} 31)\end{array}$ & 17.1 & 5251.5576 & 5251.5742 & 3.2 & 82 & 5 & 71100 \\
\hline $\begin{array}{l}\text { CDLPQTHSLGSRRTLMLLA } \\
\text { QMRRISLFSCLKDRHDFGFP } \\
\text { QEE }\end{array}$ & 1 & 42 & - & 15.2 & 4931.4565 & 4931.4678 & 2.3 & 82 & 16 & 1260371 \\
\hline $\begin{array}{l}\text { DSILAVRKYFQRITLYLKEK } \\
\text { KYSPCAWE }\end{array}$ & 114 & 141 & - & 15.9 & 3447.8376 & 3447.8484 & 3.1 & 54 & 11 & 148100 \\
\hline DSILAVRKYFQRITLYLKE & 114 & 132 & - & 16 & 2355.3313 & 2355.3396 & 3.5 & 36 & 10 & 86212 \\
\hline MIQQIFNLFSTKDSSAAWDE & 59 & 78 & -- & 17.2 & 2330.0889 & 2330.0984 & 4.1 & 38 & 30 & 230245 \\
\hline ACVIQGVGVTETPLMKE & 97 & 113 & - & 13.7 & 1773.9005 & 1773.9037 & 1.8 & 32 & 19 & 39100 \\
\hline IMRSFSLSTNLQE & 147 & 159 & -- & 13.2 & 1524.7606 & 1524.7625 & 1.2 & 24 & 13 & 77335 \\
\hline LYQQLNDLE & 88 & 96 & - & 12.6 & 1134.5557 & 1134.5563 & 0.5 & 16 & 10 & 104392 \\
\hline TLLDKFYTE & 79 & 87 & - & 13.6 & 1128.5703 & 1128.5726 & 2 & 16 & 13 & 186867 \\
\hline KKYSPCAWE & 133 & 141 & -- & 10.7 & 1110.5168 & 1110.5175 & 0.6 & 16 & 0 & 2622 \\
\hline ACVIQGVGVTE & 97 & 107 & - & 12.5 & 1074.538 & 1074.5389 & 0.8 & 20 & 8 & 28633 \\
\hline FGNQFQKAE & 43 & 51 & - & 9.8 & 1067.5035 & 1067.506 & 2.3 & 16 & 13 & 123187 \\
\hline 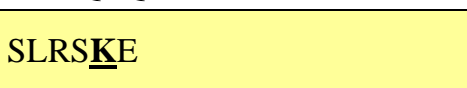 & 160 & 165 & $\begin{array}{c}\text { ZQG(1) } \\
(99 \%, \text { K164) }\end{array}$ & 11.8 & 1038.4982 & 1038.5007 & 2.4 & 10 & 4 & 189663 \\
\hline TIPVLHE & 52 & 58 & - & 11.5 & 807.449 & 807.4507 & 2.1 & 12 & 7 & 156555 \\
\hline SLRSKE & 160 & 165 & - & 2.6 & 718.3973 & 718.4 & 3.8 & 10 & 0 & 765 \\
\hline TPLMKE & 108 & 113 & - & 9.3 & 717.3731 & 717.3752 & 2.9 & 10 & 4 & 22086 \\
\hline VVRAE & 142 & 146 & - & 5.8 & 572.3282 & 572.3321 & 6.8 & 8 & 1 & 7381 \\
\hline
\end{tabular}

Lines of modified peptides are highlighted in yellow. ${ }^{a}$ Identified peptides with zero missed cleavages are reported. Peptides derived from one missed cleavage are only peptides $114-141$ and $97-113 .{ }^{b}$ The $\%$ modified corresponds to the intensity $\%$ of conjugated peptide that it is calculated according to the following formula: $100 *$ (conjugated peptide intensity/total intensity of modified and non-modified peptide). 
Table S4. Peptides of IFN identified in the digest of IFN ${ }^{1 \mathrm{DC}}$ with endoprotease Glu-C.

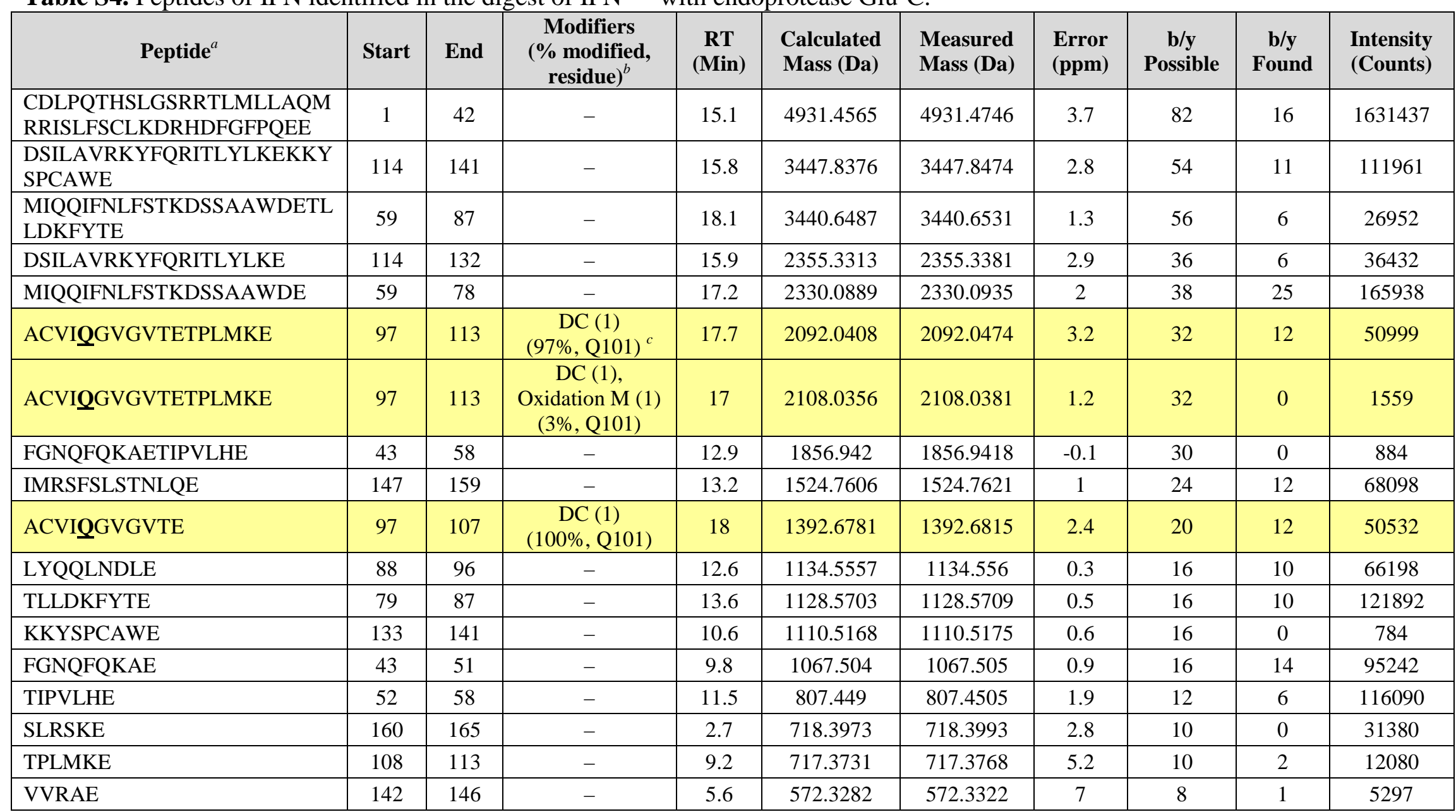

Lines of modified peptides are highlighted in yellow. ${ }^{a}$ Identified peptides with 0 missed cleavages are reported. Peptides derived from 1 missed cleavage are only peptides $114-141$ and $97-113 .{ }^{b}$ The $\%$ modified corresponds to the intensity $\%$ of conjugated peptide that it is calculated according to the following formula: $100^{*}$ (conjugated peptide intensity/total intensity of modified and non-modified peptide). ${ }^{c}$ The remaining $3 \%$ of peptide $97-113$ modified with DC is oxidized at the level of the methionine residue. 
Table S5. Calculated and measured $\mathrm{m} / \mathrm{z}$ values of the fragment ions detected in the $M S^{\mathrm{E}}$ fragment ion spectra of peptides $1-42$ and $1-42^{1 \mathrm{ZQG}}$.

\begin{tabular}{|c|c|c|c|c|c|}
\hline $\begin{array}{l}\text { Peptide } \\
\text { species }\end{array}$ & Assignment & $\begin{array}{c}\text { Calculated } \\
\mathbf{m} / \mathbf{z}\end{array}$ & $\begin{array}{l}\text { Measured } \\
\mathrm{m} / \mathrm{z}\end{array}$ & $\begin{array}{l}\text { Error } \\
\text { (Da) }\end{array}$ & $\begin{array}{c}\text { Modifiers } \\
\text { (n. of modifiers) }\end{array}$ \\
\hline \multirow[t]{17}{*}{$1-42$} & $\mathrm{~b} 2$ & 219.044 & 219.0453 & -0.0013 & - \\
\hline & b3 & 332.128 & 332.1293 & -0.0013 & - \\
\hline & b32 & 3671.9124 & 3671.9192 & -0.0068 & - \\
\hline & b33 & 3828.0134 & 3828.0105 & 0.0029 & - \\
\hline & b35 & 4080.0991 & 4080.1064 & -0.0073 & - \\
\hline & b37 & 4284.189 & 4284.1943 & -0.0054 & - \\
\hline & b38 & 4431.2573 & 4431.269 & -0.0117 & - \\
\hline & b39 & 4528.3101 & 4528.3354 & -0.0254 & - \\
\hline & $\mathrm{b} 40$ & 4656.3687 & 4656.3779 & -0.0093 & - \\
\hline & b41 & 4785.4116 & 4785.4272 & -0.0156 & - \\
\hline & $\mathrm{y} 1$ & 148.061 & 148.0607 & 0.0003 & - \\
\hline & y2 & 277.1036 & 277.1053 & -0.0017 & - \\
\hline & y3 & 405.1621 & 405.1632 & -0.0011 & - \\
\hline & $\mathrm{y} 4$ & 502.2149 & 502.2153 & -0.0004 & - \\
\hline & y5 & 649.2833 & 649.2792 & 0.0042 & - \\
\hline & $\mathrm{y} 39$ & 4601.3442 & 4601.3589 & -0.0146 & - \\
\hline & y42 & 4932.4644 & 4932.4795 & -0.0151 & - \\
\hline \multirow[t]{6}{*}{$1-42^{1 Z Q G}$} & b38* & 4751.3584 & 4751.3608 & -0.0024 & ZQG (1) \\
\hline & b40* & 4976.4697 & 4976.4771 & -0.0073 & ZQG (1) \\
\hline & b41* & 5105.5122 & 5105.5322 & -0.02 & ZQG (1) \\
\hline & $\mathrm{y} 4$ & 502.2149 & 502.2154 & -0.0005 & - \\
\hline & $\mathrm{y} 40^{*}$ & 5034.5293 & 5034.5371 & -0.0078 & ZQG (1) \\
\hline & $\mathrm{y} 42^{*}$ & 5252.5654 & 5252.5894 & -0.0239 & ZQG (1) \\
\hline
\end{tabular}


Table S6. Molecular masses of the nicked forms of IFN produced by limited proteolysis with proteinase $\mathrm{K}$ before and after reduction with TCEP.

\begin{tabular}{|c|c|c|c|}
\hline \multirow{2}{*}{$\mathbf{R T}(\min )^{a}$} & \multirow{2}{*}{ Species $^{b}$} & \multicolumn{2}{|c|}{ Molecular mass (Da) } \\
\hline & & Found $^{c}$ & Calculated $^{d}$ \\
\hline 33.9 & IFN (1-165) & $19263.95 \pm 0.07$ & 19265.16 \\
\hline \multirow[t]{5}{*}{34.1} & $1-106 / 107-165$ & $19283.87 \pm 0.09$ & 19283.17 \\
\hline & $1-103 / 104-165$ & & \\
\hline & $1-103 / 107-165$ & $19026.48 \pm 0.19$ & 19025.88 \\
\hline & $1-106 / 107-161$ & $18783.11 \pm 0.34$ & 18782.62 \\
\hline & $1-103 / 107-161$ & $18525.93 \pm 0.18$ & 18525.33 \\
\hline \multirow{5}{*}{$\begin{array}{c}34.1 \\
\text { (after reduction } \\
\text { with TCEP) }\end{array}$} & $1-106$ & $12244.50 \pm 0.41$ & 12244.98 \\
\hline & $1-103$ & $11987.39 \pm 0.23$ & 11987.69 \\
\hline & $104-165$ & $7299.07 \pm 0.31$ & 7299.51 \\
\hline & $107-165$ & $7041.93 \pm 0.15$ & 7042.22 \\
\hline & $107-161$ & $6541.43 \pm 0.13$ & 6541.67 \\
\hline
\end{tabular}

${ }^{a}$ Retention times refer to the RP-HPLC analysis of the reaction mixture of IFN with proteinase K after 15 min of incubation (see Figure S5). ${ }^{b}$ The nicked protein species in their oxidized form are made by disulfide-crosslinked fragments. The reduced fragments were produced upon incubation with TCEP. ${ }^{c}$ Experimental molecular masses determined by ESI-MS. ${ }^{d}$ Calculated average molecular masses. 